\title{
Lombok earthquake, one year later: housing sector recovery
}

\author{
Krishna S Pribadi ${ }^{1, *}$, Rani G Pradoto ${ }^{1}$, Eliya A Hanafi ${ }^{1}$, and I Made Adhi Bayu Rasmawan ${ }^{1}$ \\ ${ }^{1}$ Construction Engineering and Management Research Group, Faculty of Civil and Environmental Engineering, Bandung Institute of \\ Technology, Jl. Ganesha 10 Bandung 40181, Indonesia
}

\begin{abstract}
The series of strong earthquakes that hit the province of West Nusa Tenggara (NTB) on 29 July 2018 (M6.4), 5 August 2018 (M7.0), 9 August 2018 (M6.2) and 19 August 2018 (M6.5 and M6.9) has caused many casualties, injuries as well as damages in the housing sector. The disaster emergency was stated on July 29th, 2018 and was extended several times up to August 25th, 2018. A transition period from an emergency situation to recovery was declared starting from August 26th, 2018 to February 26th, 2019, while the rehabilitation and reconstruction (R \& R) phase was started from February 27th., 2019. In the R \& R program, the Government has established a policy of building earthquake-resistant houses with a self-managed system through the formation of community groups (POKMAS) consisting of house owners, supported by technical and administrative facilitators. There are many models of earthquake resistant houses, both those proposed by the government and the private sector that are approved by the government. A Presidential Instruction (Inpres) Number 5 Year 2018 was issued on 23 August 2018 to provide guidance on the housing sector reconstruction. An investigation to study and document the lessons learnt from the housing reconstruction process is conducted in Lombok Island, covering the issues of program management, institutional set up and coordination, project administration, technical design, quality assurance and community participation. It was found that there were so many house building models proposed to the community by various sponsors, which cause confusion to the affected community. The study also found that the house reconstruction program has been delayed during the process, as one year after the earthquake, there were only about 52 thousands houses which have been completed, and 80 thousands other are still in progress, compared to the total of more than 237 thousand affected houses to be repaired and rebuilt. The study is expected to reveal various impeding issues and propose solutions for expediting the process. It is also expected that the result of the study can be used as a reference for future post-disaster housing sector recovery program in other places.
\end{abstract}

\section{Introduction}

The series of strong earthquakes that hit the province of West Nusa Tenggara (NTB) on 29 July 2018 (M6.4), 5 August 2018 (M7.0), 9 August 2018 (M6.2) and 19 August 2018 (M6.5 and M6.9) has caused many casualties, injuries as well as damages in the housing sector (total 149,706 houses were heavily damaged). The disaster emergency was stated on July 29th, 2018 and was extended several times up to August 25th, 2018. A transition period from an emergency situation to recovery was declared starting from August 26th, 2018 to February 26th, 2019, while the rehabilitation and reconstruction (R $\&$ R) phase was started from February 27th. , 2019.

In the $\mathrm{R} \& \mathrm{R}$ program, the Government policy was to provide the affected community with aid to rebuild their houses which are expected to be more earthquakeresistant. The government aid is provided through groups of house owners (POKMAS) which are supposed to manage their own procurement and construction process, supported by government technical and administrative facilitators. Several models of earthquake resistant houses, both those proposed by the government and the private sector, were already approved by the government. A Presidential Instruction (Inpres) Number 5 Year 2018 was issued on 23 August 2018 to provide guidance on the housing sector reconstruction. The government has established an R \& R Task Force structure consisting of various government sectors to manage the $R$ \& $R$ program. Housing reconstruction is one of its priority. However, field findings show that the rehabilitation and reconstruction program has been delayed during the process, as one year after the earthquake, there were only about 52 thousands which have been completed, and 80 thousands other are still in progress, compared to the total of more than 237 thousand affected houses to be repaired and rebuilt. Many displaced people still have to live under temporary shelters. Field actors feel that there is confusion when it come to who should provide approval on the various house aid schemes, including the technical specification of the construction, supervision and liquefaction of government relief fund.

In order to understand what happens in the field related to various issues, an investigation to study the whole processes and to document the lessons learnt from the reconstruction process is conducted in Lombok Island, which covers various aspects such as legal framework, program management, institutional set up and coordination, project administration, technical design, quality assurance and community participation. Challenges and impediments are identified and discussed. The study is expected to bring light to various impeding

\footnotetext{
* Corresponding author: kspribadi@gmail.com
} 
issues and propose solutions for expediting the process. It is also expected that the result of the study can be used as a reference for future post-disaster recovery program in other places, in particular in the housing sector.

\section{Post-disaster Housing Reconstruction}

One of the most important sectors in post-disaster recovery is housing reconstruction. However, housing reconstruction projects in the past have often faced with enormous challenges associated with community participations; program management, institutional set up and coordination, project administration, technical design and quality assurance. It has been well established that reconstruction process should provide the affected people with safer houses and more resilient community, beside socio economic recovery. For this reason, community participation involving all stakeholders, especially the affected communities in reconstruction [1] has been considered as a better approach to induce awareness and knowledge on earthquake safer house building practice. More over, the approach can also provide opportunities for the affected community to re-establish and improve livelihood through construction activities. It is expected that people who are engaged in the reconstruction process with proper guidelines and supervision will gain better knowledge and skill on earthquake resistant house building, which will be useful for future resilient building and their future life. It is generally believed that participatory process among community is an efficient method for housing reconstruction and disaster awareness of participants about 10 years after the "build back better" [2] . In addition, good program and project management approach, strong coordination and project administration are essential for a successful post-disaster housing reconstruction program.

The management issues of housing reconstruction play a crucial role in rebuilding communities. A framework for project management of post disaster should provide practical guidance for policy makers and practitioners. Several issues of management for permanent housing reconstruction (PHR) were identified which is the strategic importance of communities' preparedness; The need for sound initiation of the reconstruction program based on a thorough damage and loss assessment, and taking into consideration the needs of affected communities towards; The establishment of a legislative, regulatory and policy framework that provides direction for stakeholders; The need for critical assessment of communities' vulnerability and identification of existing and underlying hazards and disaster risks; The need for beneficiary community engagement in the reconstruction process is essential to give them ownership of the program; The provision of education and capacity building for stakeholders throughout the PHR management process [3]. Furthermore, it has been proven that the development of general framework improved data collection for further research in order to improve management practices for housing sector of post disaster [4].
In terms of post disaster program, good governance plays an important role for influencing the recovery process of housing sector. The rehabilitations of disaster could potentially be long and complex process in disposition and responsibility between central government and local contents. In order to overcome the long process, the good governance should reduce the distance between them [5].

From previous study, good practices have been established in several post-disaster housing reconstruction programs for better strategies in conducting sustainable of housing environment. From earthquake in Aceh (2004), Yogyakarta (2006), West Java (2009) and West Sumatera (2009) reveals that training and knowledge in building of construction personnel and home-owners, through the dissemination of guidelines and manuals as well as building codes and standards for anti-seismic design. The programs are implemented by the national and local governments, NGOs. Builders and masons are trained from aid agencies. But in general, the performance of the building industry as well as local government building administrators for safety resilience houses still need to improve.[6]. In addition, the minimum compliance to the regulations and building codes should be examined to have a proper knowledge in earthquake design structures. And also, combined efforts and coordination of government and research agencies, construction developers, construction personnel (contractors, technicians, masons and crafts) and the community are necessary in improving building performance towards future earthquakes. A technical design and procedure for building construction method are needed so that reconstruction program meet the demand of the communities.[7,8].

\section{Methodology}

The field surveys were conducted through interviews to various parties in the earthquake affected areas, which include house owners, masons and craftsmen, local builders/applicators (specific term used for firms or individual who propose to build houses following a certain approved prototype models), government officers involved in the recovery program, NGOs, material suppliers and other respondents., which is rather confusing for the community groups. Due to the time limitation, the survey was limited to several selected samples of housing types and the building was randomly selected included those constructed by the applicator or joint-communities. Community groups formed from 10 to 20 house owners, which is called POKMAS (community group) are interviewed on different issues, such is how they decide to select an approved prototype model to be constructed, how they decide on the project delivery method, whether in self construction/force account mode or by builder/applicator, how they receive government relief aid and how the perceive the support by government assigned facilitators.

The survey team also visited a workshop where different prototype of houses with sufficient information about construction method and design approval from local 
agencies and which certified applicator as builder are showed. It provided an overall view concerning building technology in terms of fast construction and safe houses.

Discussions with local actors were conducted to get information on problems and obstacles in the fields related with the mechanism and project delivery, and how they are solved.

The study proposes an overview of on-going reconstruction program and actual rebuilding practices one year after the disaster, including the challenges faced by the program.

\section{Findings}

An updated data (10 $0^{\text {th }}$ July, 2019) from Nusa Tenggara Barat (NTB) Provincial Disaster Management Agency shows that 222.564 houses were damaged by the earthquakes (75.138 heavy damage, 33.373 medium damage, 114.053 light damage), mostly in Lombok island (more than 180 thousands).

Rehabilitation and reconstruction effort started soon after the third earthquake occur on August $19^{\text {th }}$. On August $23^{\text {rd }} 2018$, President of The Republic of Indonesia signed a Presidential Instruction (Inpres) No 5 year 2018 as a legal guidance for acceleration of rehabilitation and reconstruction effort. Specifically in housing sector, The Ministry of Public Work and People Housing (MPWH) was instructed to provide guidance and supervision in the construction of earthquake resistant housing with selfmanaged system by the community [9].

On September $10^{\text {th }} 2018$, MPWH through Disaster Relief Task Force deployed facilitators to NTB in order to assist the affected people in rebuilding their houses.

\subsection{Program Management}

The affected houses were divided into three categories namely lightly damaged (RR), medium damaged (RS), and heavily damaged (RB). Houses with light and medium damage will be repaired and renovated while heavily damaged houses will be re-build with earthquake resistant structure features (RTG).

The government provide relief aid in the form of stimulating fund, which is allocated from National Budget (APBN) for housing sector reconstruction. The amount is based on the category of damage level i.e. 50 million rupiah for heavily damaged houses, 25 million rupiah for medium damaged houses, and 10 million rupiah for lightly damaged houses [9]. Beneficiaries were asked to form community groups (POKMAS) to utilize and manage the stimulating fund, the intention was to implement self-managed system as a form of community empowerment. For the planning and construction of the earthquake resistant houses, POKMAS were accompanied by facilitators, which consist of technical and administrative (social and economy) facilitators. Facilitators were expected to help POKMAS mainly during construction phase, such as giving technical guidance and preparing administrative document for fund utilization.

\subsection{Institutional and Legal Framework}

Regulations used as guidance in rehabilitation and reconstruction effort in the province of Nusa Tenggara Barat are as follow:

1) Presidential Instruction (INPRES) No 5 year 2018

2) Implementation Guidance (JUKLAK) of stimulating aid for housing repair by National Agency for Disaster Management (BNPB) year 2018

3) Governor of NTB Regulation (PERGUB) No 35 year 2018

4) Governor of NTB Decree (SK) No 360-12 year 2019 Bank Rakyat Indonesia (BRI) is appointed as the only bank to distribute the stimulating fund by creating individual accounts of the beneficiaries.

The authority for guidance and supervision through facilitators is divided between central and local government:

- Repair and rehabilitation effort and recruitment of facilitators for lightly and medium damaged houses are coordinated under the NTB Provincial Agency for Disaster Management (BPBD)

- Reconstruction effort and recruitment of facilitator for heavily damaged houses are coordinated by MPWH through Disaster Relief Task Force (SATGAS) with rehabilitation and reconstruction of people and housing based on community empowerment program.

After mid-April 2019, full responsibility for rehabilitation and reconstruction effort has been transferred from MPWH to the provincial government i.e. BPBD and Provincial Housing Agency (PERKIM). Discussions with stakeholders revealed that there were confusion in terms of responsibilities of various agencies involved in the process.

\subsection{Project Delivery Mechanism}

Following the Presidential Instruction, the mechanism adopted for housing reconstruction is a force account method or self-managed system. During the period when MPWH was in charge of reconstruction for heavily damaged houses, there were two self-managed schemes:

- Pure self-managed system, where POKMAS purchases material and provides manpower. Usually POKMAS will hire workers (workers can also completely/partially come from member of POKMAS itself) to carry out the construction.

- Partial self-managed system, where POKMAS may hire builder, such as in the case of installation of RISHA system's precast beams, columns and panels, which is a sophisticated scope of work unable to be carried out by the community (specific skills and tools are required), although POKMAS may still purchase some material by themselves.

Both schemes above proceeded well, especially when supported by sufficient number of facilitators and for a limited number of house types to be chosen by POKMAS (at first there were only three types of house introduced).

However, despite the well-accepted self-managed system, the progress of housing reconstruction was slow 
with all the problems it faced. To accelerate the progress, the provincial government accepts proposals for other alternatives of house prototypes from various actors (NGOs, private sector, universities) as long as they meet the requirement for earthquake resistant houses. Following the introduction of the new models, a new project delivery method is adopted in addition to the already existing schemes, i.e. fully contracted to builder. This option is adopted to accommodate more complicated construction method of the new prototypes. POKMAS still has the right to decide the term of agreement with the builders (which are often called as applicators of the new construction technology).

The availability of this option provides new business opportunities for many new builders to take part in the process. They claim as applicators that they can build earthquake resistant houses faster and cheaper, compared to the more conventional models. Up to the time of this field observation, most of the house reconstructions were implemented using builder contractual scheme, mainly because the local people assumed that by contracting the house construction, it will finish faster while avoiding the complexity of material purchasing or participating in building their houses.

\subsection{Technical Design}

At first, the government approved three prototypes of earthquake resistant house. Since the progress was slow, resistant and can be constructed quickly. During its first implementation, it appears that many applicators (RISHA concrete beam, column and panel suppliers) were unable to fulfil production demand. This is the reason why eventually other prototypes of houses were introduced.

The confined masonry house (RIKO) and timber structure house (RIKA), which were actually a conventional building technology commonly known by local people, were the two models later on adopted for the reconstruction, where the government only needs to enforce the earthquake resistant standard requirements. Other problem emerge though, as many peoples are interested in timber structure house while suitable timber material availability was limited, the government had then to curb its production. Another issue arises, the conventional confined masonry house requires large number or workers and long completion time. All these issues bring to the decision to approve more prototypes of houses promoted by various parties. Up to the time of the field observation, approximately a total of 18 types of houses has been introduced and recommended for accelerating the progress (see Fig.1).

All house types were standardized in design and floor size, as 36 Type houses (36 sq.mtr floor size) as shown in Fig. 1. The standard designs are used as a guidance to build the earthquake resistance houses, but home owners can ask for a larger house provided that they add their own fund and it usually depends on the consensus among the POKMAS members or agreement between POKMAS and builder.


RISBA
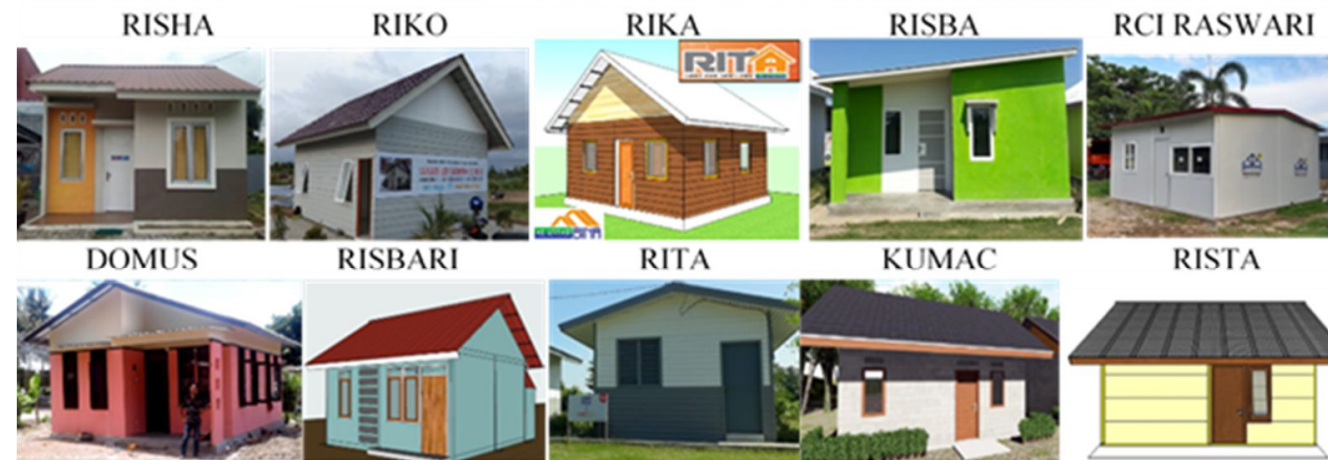

RITA

KUMAC

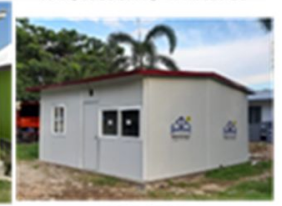

BALE LESTARI

RAPI

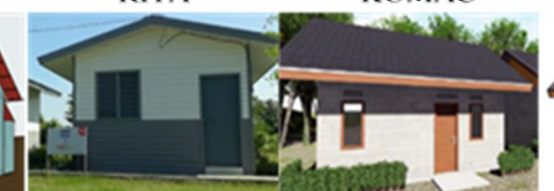

RAISHA

RISDA
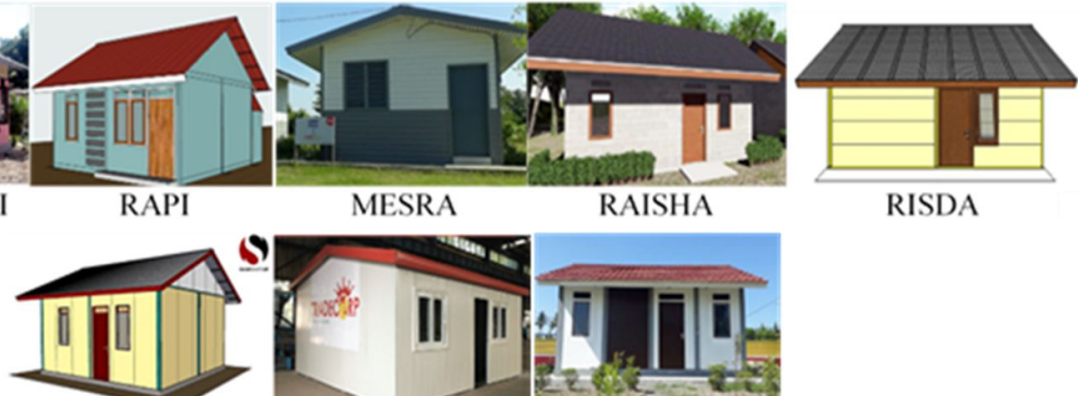

Fig. 1. Standard designs approved for earthquake resistant house in Lombok.

the government introduced more prototypes of house, so eventually there were 18 prototypes approved for accelerating the reconstruction process. RISHA, a prefabricated precast house prototype, which was developed more than a decade ago by the Housing Research and Development Centre (PUSKIM) - MPWH, was the first option adopted for the post-disaster reconstruction in Lombok, as it is considered earthquake
Despite the many new types of houses introduced, RISHA, conventional confined masonry house (RIKO), timber structure house (RIKA), and steel structure house (RISBA) are the most popular prototypes chosen by the communities, other than that only a small number of houses that were built by the POKMAS ( \pm 3000 houses). In practice, despite of standard design and technical specification, some differences between what are 
specified and what were built still can be found, as shown in Fig. 2 to Fig. 4.

Enforcement of standard (quality assurance) through supervision was supposed to be the key to ensure the structural strength of building. In order to achieve the goal to strengthen community awareness on how to build earthquake resistant house, strict supervision by technical facilitators are required strongly.

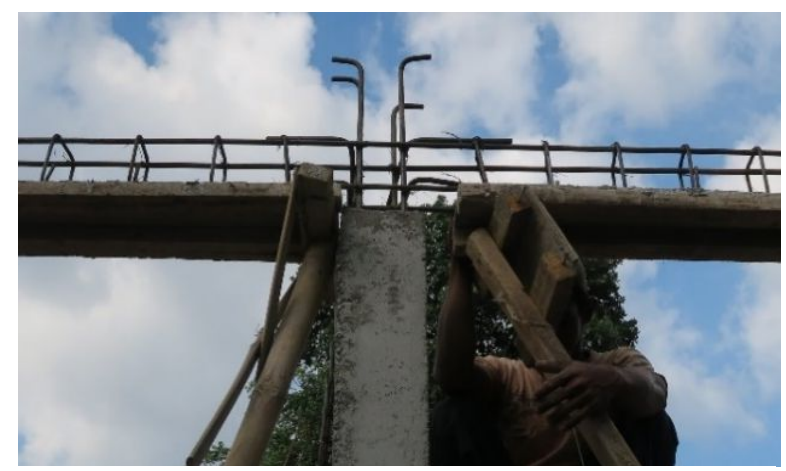

Tulangan kolom dilewatkan ke balok ring dengan pan
$40 \times \varnothing(40 \mathrm{~cm})$

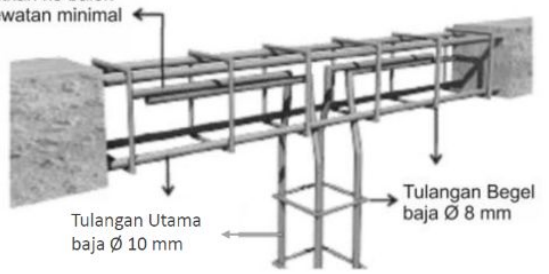

Fig. 2. Beam-column connection in conventional confined masonry house (RIKO), field finding (above) and technical requirement (below).

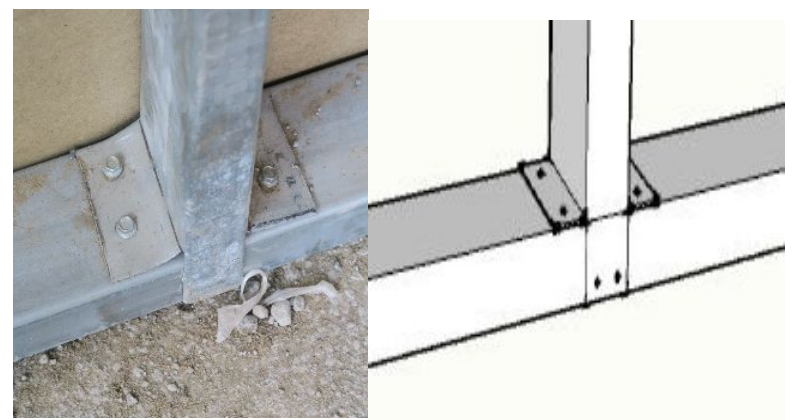

Fig. 3. Column-grade beam connection in galvanized steel structure house (BALE LESTARI), field finding (left) and technical requirement (right).

\subsection{Project Administration}

As a massive reconstruction program, substantial amount of documents are needed to control and evaluate the process. This section will describe the implementation of project administration in terms of housing reconstruction in Lombok.

\subsubsection{Administration for Housing Reconstruction}

When the emergency response phase was changed to transition phase, the government prepared and provided the funding for housing reconstruction through these flow of stimulating fund, as followed:

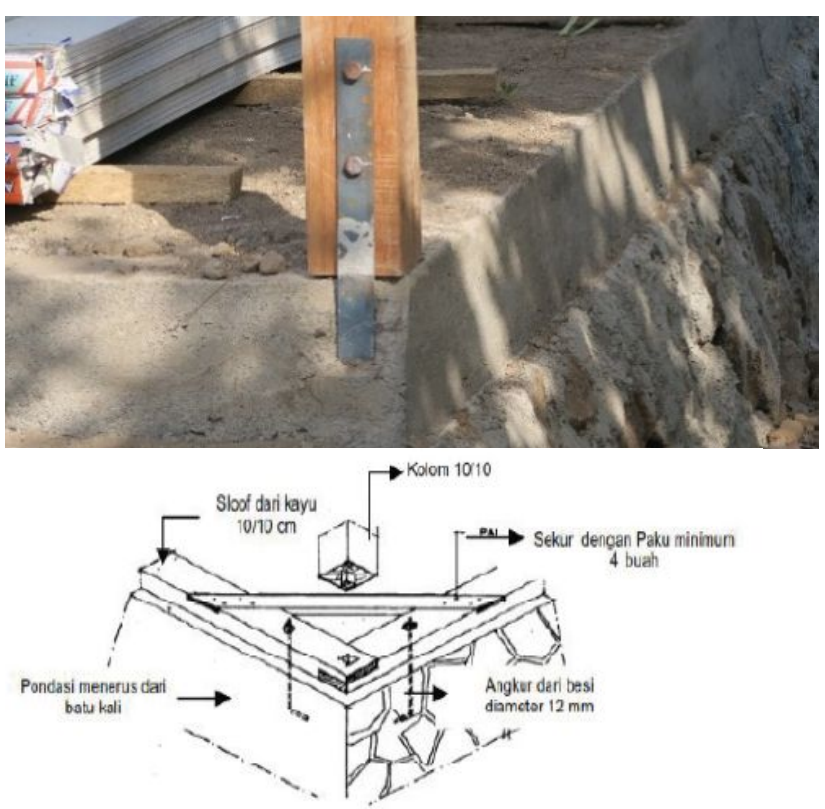

Fig. 4. Column-grade beam connection in timber house (RIKA), field finding (above) and technical requirement (below).

1. Housing verification by regional technical team

2. Statement letter from local leader (Mayor/ Regent)

3. Proposal for stimulating funding from Mayor/Regent to BNPB (National Disaster Management Agency)

4. Review and proposal from BNPB Inspectorate to Ministry of Finance

5. Approval and remittance from Ministry of Finance to BNPB

6. Funds transfer from BNPB to Officers of BPBDs in charge of making commitment with the POKMAS in city/region, called the PPKs.

7. Funds transfer from PPK of BPBD in the city/region to personal (community) bank account

8. Funds transfer from community member of POKMAS to POKMAS bank account by completing required documents

9. Funds transfer from POKMAS to the third party/applicator/builder or supplier

10. Cash payment from POKMAS to labour/worker.

In accordance with the procedure, the community is taking a big part of financial management since the stimulating fund was transferred to their personal bank account. This is related to management of administration of housing reconstructions that mostly managed directly by POKMAS accompanied by facilitator. During this process, some of required administrations are needed to be prepared and completed. According to the guideline, there are:

1. Forms for damaged house record

2. Technical construction documents, including house model/type, budget plan, work plan and procurement.

3. Report of establishment of POKMAS 
4. Statement letter from head of village for establishment of POKMAS

5. Copy of POKMAS member identity

6. Letter of right of use in land

7. Photos of physical condition at $0 \%$

8. Bank Account

9. Form 1 : Validation form of beneficiaries

10. Form 2 : Budget plan for housing reconstruction

11. Form 3 : Letter of commitment for completing all housing reconstruction works

12. Form 4 : MoU of stimulating fund management

13. Form 5 : List of POKMAS nominative member

14. Form 6 : List of POKMAS nominative beneficiaries

15. Form 7 : Recommendation letter for disbursement of stimulating funds

16. Form 8 : Receipt of housing reconstruction

17. Form 9 : Shop drawing of house

18. Form 10.1 : Progress report of Construction work

19. Form 10.2 : Documentation report of work standard compliance

20. Form 11 : Authorization letter of debt account

The PPK (responsible officer in charge of the project) of BPBD region/city will evaluate the documents (No.114 and 17) and issue a letter of recommendation to the Bank for transferring the stimulating fund to POKMAS.

The disbursement of stimulating fund will be done collectively to POKMAS members based on the recommendation letter and statement letter of fund withdrawal (signed by head and treasurer of POKMAS). The disbursement of stimulating fund is divided into 3 phase, $\mathrm{I}=50 \%, \mathrm{II}=30 \%$ and $\mathrm{III}=20 \%$ from total funds in POKMAS bank account. Disbursement is based on the compliance with the technical standard of earthquake resistant house, evaluated by the facilitators.

\subsubsection{Administration for Applicator}

It was found that there were two types of applicator, first is the applicator/supplier who propose a new model of earthquake resistant house as well as build the house, and second is the applicator who only build the house.

Some procedure should be completed by the third party/applicator who proposed for a new type of earthquake resistant house model, at least:

- Proposal of earthquake resistant house

- Technical guidance of earthquake resistant house, including the procedure, material, specification etc.

- Report of structural analysis

- Budget plan

- Shop drawing

- Integrity pact

While completing all documents, the applicator should conduct some test and get recommendation from Agency of Housing and Settlement (PERKIM) of NTB Province or Research and Development Centre for Housing and Settlement, MPWH. Next, the applicator team will present their proposed model to a certain team in provincial level, including related stakeholders and government to verify and evaluate model and applicator.
If accepted, the applicator will get permit to start working and open market or construction in NTB.

Applicators who build only houses (builder) need to sign an integrity pact. Special case in East Lombok Region, the government appointed a special team to verify and validate the applicator, not only through integrity pact but also including their track record and factual survey.

\subsection{Quality Assurance}

To ensure quality of the earthquake resistant houses, it is highlighted the needs for effective supervision and inspection, without which, failures could occur in terms of the monitoring and quality control of the housing reconstruction. However during the site visit and survey, the authors and related local stakeholders found several houses under-construction with poor quality.

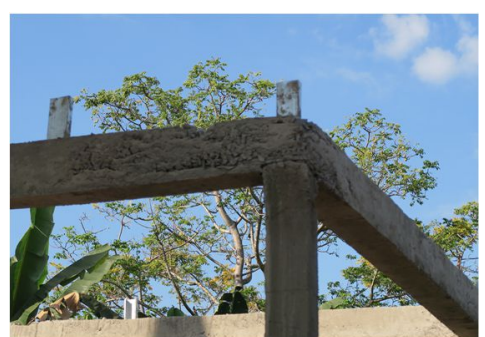

(a)

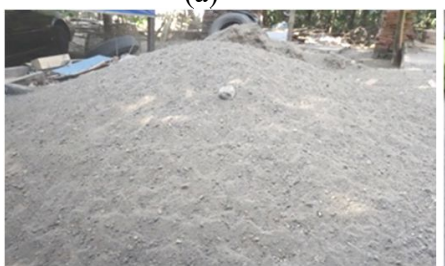

(c)



(e)

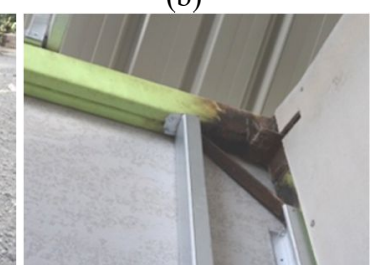

(d)

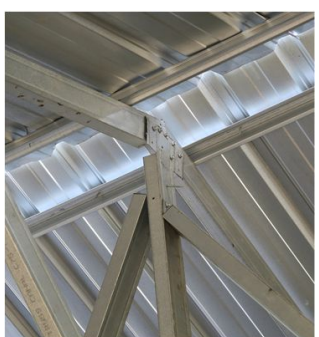

(b)
Fig. 5. Some of examples of poor workmanships identified in the field include: (a) concrete quality problem, (b) improper joining of light gage steel truss, (c) poor quality sand, (d) poor quality welding work, (e) bad workmanship of brick laying

Typical problem that shows up during the survey is non-compliance to the structural technical requirement. The concrete strengths in most of the cases are lower than the required standard for earthquake resistant house (K175). It seems finding good quality sand in Lombok is challenging, most of the sand used in the projects have high silt and clay content. Timber quality is often bellow the specified class III. Workmanships for steel structures are bellow standard, welding of beam and column joint is often improper, truss joint method questionable. These circumstances could not be avoided due to inadequate supervision and inspection. The facilitators who are supposed to monitor and supervise construction works are 
limited in number and technical knowledge. Each of the facilitators has to handle a large amount of house reconstruction projects in each district. Technical facilitators with engineering background are very limited in number compared to those with non-engineering background.

Workmanship for non-structural elements also needs attention, such as the brick laying of walls where mortar joins are usually too thick (20-30 mm instead of 10-15 $\mathrm{mm})$. The problems related to construction quality tend to undermine the objective of "build back better" in the recovery process.

\subsection{Current Progress}

Despite the Presidential Instruction (INPRES) Number 5 Year 2018 target to finish reconstruction by the end of 2018, after one year, a modest progress of rehabilitation and reconstruction across affected regions in Lombok Island is observed. Some improvements have been seen after January 2019, where instruction for accelerating the recovery process was issued. However, up to July 2019, progress has been somewhat slow due to various challenges in the field, as shown in Table 1. During the process, about 3.400 facilitators have been involved to support the process, which include about1.000 army personnel (TNI), 1.000 policemen (POLRI) and 1.700 civilian.

Table 1. Current progress (Source: Perkim NTB, 10 July 2019)

\begin{tabular}{|c|c|c|c|c|c|}
\hline $\begin{array}{c}\text { Category } \\
\text { of } \\
\text { damage }\end{array}$ & $\begin{array}{c}\text { No. of } \\
\text { Facili- } \\
\text { tator }\end{array}$ & $\begin{array}{c}\text { No. of } \\
\text { POK- } \\
\text { MAS }\end{array}$ & $\begin{array}{c}\text { Damaged } \\
\text { Houses } \\
\text { (units) }\end{array}$ & $\begin{array}{c}\text { Under } \\
\text { Constr. } \\
\text { (units) }\end{array}$ & $\begin{array}{c}\text { Complete } \\
\text { d (units) }\end{array}$ \\
\hline Heavy & 1.527 & 4.978 & 75.138 & 27.034 & 12.901. \\
\cline { 1 - 4 } Moderate & \multirow{2}{*}{1.873} & 1.088 & 33.373 & 16.053 & 8.928 \\
\cline { 1 - 4 } Low & & 2.978 & 114.053 & 37.356 & 30.505 \\
\hline TOTAL & \multirow{2}{*}{3.400} & 9.044 & 222.564 & 80.443 & 52.334 \\
\hline
\end{tabular}

The distribution of the heavily damaged houses reconstruction by type of house is shown in Fig.6. The conventional confined masonry (RIKO) is the most adopted solution by the POKMASs, followed by precastprefab structure (RISHA) and the timber structure house (RIKA).

The government has been allocating fund for housing reconstruction in NTB in the amount of 5.110.900 Million Rupiah. This fund is distributed to personal (community) bank account and POKMAS Bank account, as shown in Table 2.

\subsection{Community Perception}

NTB Earthquake has caused massive destruction of houses and property, loss of financial resources, injury and illness to the people within the community. These experiences have developed severe post-traumatic and affect the community.

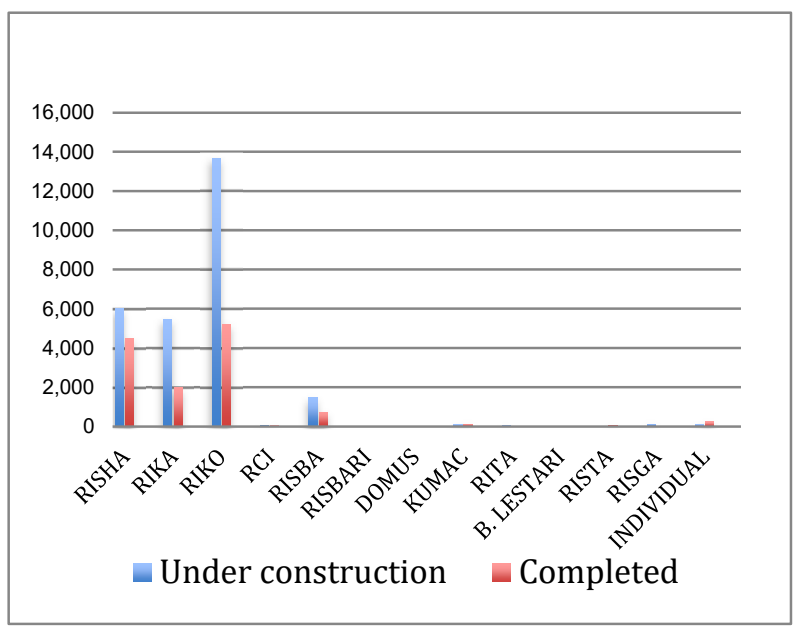

Fig. 6. Distribution of reconstruction work by type of house (Source: Perkim NTB update 10 July 2019)

Table 2. Allocated grant (source: Perkim NTB, 10 July 2019)

\begin{tabular}{|c|c|}
\hline $\begin{array}{c}\text { Total Transferred Fund } \\
\text { to community }\end{array}$ & $\begin{array}{c}\text { Stimulating Fund } \\
\text { (Million IDR) }\end{array}$ \\
\hline $\begin{array}{c}\text { Stimulating fund at } \\
\text { community (personal) } \\
\text { bank account }\end{array}$ & 4.864 .139 \\
\hline $\begin{array}{c}\text { Transferred fund to } \\
\text { POKMAS }\end{array}$ & 3.921 .284 \\
\hline
\end{tabular}

During the interviews (see Fig. 7), most of the people in the community admitted that they were traumatized by the fact that many people were injured and killed in their brick masonry and concrete houses. Therefore, they prefer timber houses (RIKA) for their reconstructed houses. It has similarity with their traditional houses and they believe that it is safer during earthquake.

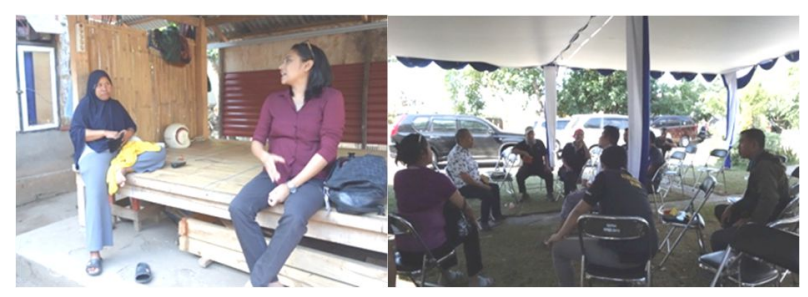

Fig. 7. Interview and discussion with community

As timber material is considered as a scarce resource and increase in illegal logging has been observed, the government limited the construction of RIKA houses. Due to this policy, the community opted for confined masonry houses (RIKO) as they were familiar with the construction method, with some modifications by limiting the brick wall infill height up to $60 \sim 100 \mathrm{~cm}$, and followed by light facade materials such as bamboo or fibre board materials, as shown in Fig. 8. 


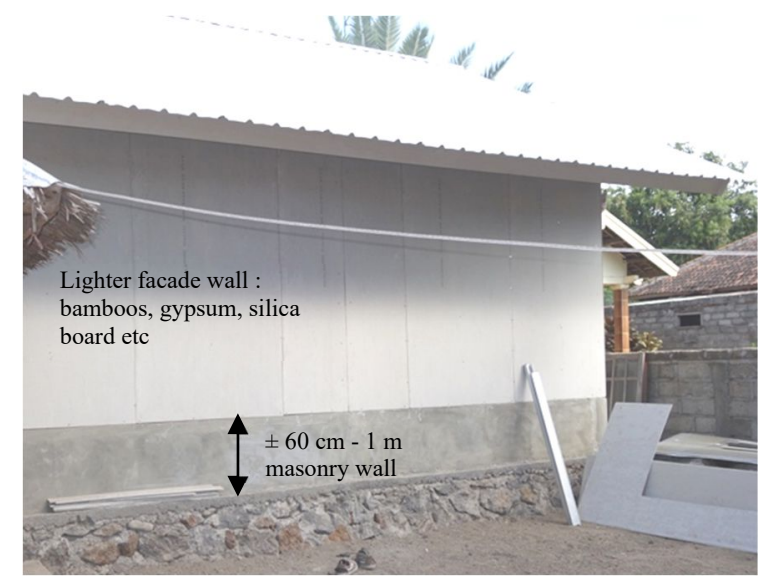

Fig. 8. Modified confined masonry wall.

Community preference for other new types of earthquake resistant house is much less than for the timber or conventional masonry house. As shown in Fig.6, the majority of people opted for the conventional confined masonry houses. Most house owners and POKMAS members expressed their confusion toward the too many choices of earthquake resistant house types. They prefer to choose the more familiar design of RIKO, which was supposed to be a confined masonry type house but modified to use lighter facade wall materials.

There are three modes of community participation in the housing construction process, i.e. full participation (scheme 1), partial participation (scheme 2) or no participation at all (scheme 3). Most of the people opted for scheme 2 with partial contractual scheme, and scheme 3 for full contractual scheme in the construction of their houses. Minimum participation from the owner of the house is in the form of supervision of the construction works. There are only a few POKMAS where community participate as workers due to limited skills.

The community is encouraged to adopt the concept of Build Back Better for recovery and reconstruction through the transfer of knowledge on earthquake resistant house technology during the reconstruction process. The findings shows that most of POKMAS with RIKO house get better knowledge on basic or technical knowledge for earthquake resistant house, in particular related to concrete material composition of stone aggregate-sandcement-water ratio, also on rebar specification, etc. However, house owners who did not join POKMAS and/or those who fully contracted their house reconstruction do not have the opportunity to improve their knowledge on earthquake resistant house technology.

\subsection{Problem and Challenges}

Despite government, community, and private sector efforts in the post-disaster recovery and reconstruction, significant challenges are still faced in the process. Several issues and challenges are summarized in Table 4, identified during the interviews and site visit in Lombok Island, especially in West Lombok, East Lombok, and North Lombok.
Table 4. Problems and challenges affecting the management of housing reconstruction.

\begin{tabular}{|c|c|}
\hline Issues & $\begin{array}{c}\text { Challenges Affecting Housing } \\
\text { Reconstructions }\end{array}$ \\
\hline Human Resources & $\begin{array}{l}\text { - limited number of facilitators, especially } \\
\text { those with engineering background, } \\
\text { faced with huge volume of work, very } \\
\text { high work-load per facilitator; } \\
\text { - lack of skilled labour and technical } \\
\text { experts } \\
\text { - lack of resources for monitoring and } \\
\text { supervision in the field }\end{array}$ \\
\hline $\begin{array}{l}\text { Logistics, Material } \\
\text { and Suppliers }\end{array}$ & $\begin{array}{l}\text { - limited timber material for RIKA, in } \\
\text { quantity and quality } \\
\text { - poor material quality for RIKO, in } \\
\text { particular sand and aggregates } \\
\text { - inadequate and uncertified supplier or } \\
\text { applicator for RISHA } \\
\text { - non-trustable applicator/supplier as the } \\
\text { third party, resulting in fraud and } \\
\text { unfinished works } \\
\text { - difficult site access in some areas }\end{array}$ \\
\hline $\begin{array}{l}\text { Financial and } \\
\text { Administration }\end{array}$ & $\begin{array}{l}\text { - complex administration procedure and } \\
\text { documentation for POKMAS for relief } \\
\text { fund disbursement } \\
\text { - limited branches of the appointed Bank } \\
\text { for fund disbursement in the region } \\
\text { - inadequate data coordination at the } \\
\text { provincial level }\end{array}$ \\
\hline $\begin{array}{l}\text { Monitoring and } \\
\text { Control }\end{array}$ & $\begin{array}{l}\text { - lack or inadequate monitoring and } \\
\text { supervision, } \\
\text { - inadequate training and mentorship } \\
\text { - insufficient regulatory mechanism to } \\
\text { enforce building codes, construction } \\
\text { guidelines and quality management } \\
\text { procedures }\end{array}$ \\
\hline $\begin{array}{l}\text { Coordination and } \\
\text { Communication }\end{array}$ & $\begin{array}{l}\text { - inadequate/unclear distribution of } \\
\text { resources, roles and responsibilities } \\
\text { - inadequate beneficiary participation and } \\
\text { engagement during implementation }\end{array}$ \\
\hline
\end{tabular}

\section{Discussion}

Investigation by PUSKIM [10] shows that most of heavily damaged or collapsed houses were unconfined masonry or confined masonry structure with inadequate beam and column elements with improper reinforcement such as small size reinforcing bars, inadequate stirrup, improper beam-column connection (not enough splice and hook length), low quality material (concrete and brick) etc., which mean that there is not enough knowledge and understanding of requirements for earthquake resistance house in the region which is understood as having high seismicity level. On the other side, as in any other major post-disaster situation, challenge on the logistic issue of appropriate construction material and availability of skilled worker will always be an issue to be solved, considering the very high spike in demand of materials and skilled labour for rebuilding need.

The post-earthquake recovery and reconstruction process in NTB should provide a good opportunity to 
improve the community and craftsmen knowledge and skill in building earthquake resistance houses, providing adequate training and guidance to builders and masons, as well as to the community during the housing reconstruction process. Adequate investment should be allocated to provide qualified facilitators to maximize the quality of the community learning process. As it is evident that most of the community opted for conventional confined masonry structure, albeit with some modifications in design of the masonry wall, it is very important to capitalize on the existing knowledge and skills of the local builders and craftsmen by bringing attention to the requirement compliance. Available earthquake resistance house guidelines and standards need to be more strongly disseminated to local community and builders. The promotion of prototypes of house which require technology and materials not common to the region seems to be counter-productive to the objective of improving the local knowledge and skill of building earthquake resistance houses. It has to be recognized that in the future the community will still be attached to the traditionally well known confined masonry technology, hence improving the local builders and masons knowledge and skill on this is very important.

Other issues arising from the many promoted house prototypes is the confusion of the local community in opting for any specific house prototype. Many local people end up with accepting proposal from so called applicators of new house prototypes without understanding the technology requirement and hence receiving bellow standard products or worse left by nontrustable applicators after they received advance payment. To optimize the housing reconstruction program, it is very important to have clear objective and policy, strong program management team and leadership, good coordination, communication and supervision among the parties involved in the program, i.e. government task force team, local engineers, local builders, suppliers, technician and facilitators and the community groups (POKMAS). Nonetheless a good database of validated data on affected houses that need interventions is a crucial factor for program implementation effectiveness.

In particular, for earthquake hazard prone areas like NTB Province, it is of the utmost importance that local government agencies and local leaders are prepared for future post-disaster recovery programs, by strengthening post-disaster recovery planning and implementation and preparing adequate SOPs for that purpose.

Despite the rule that on call budget is normally allocated only for post-disaster emergency response and not to build permanent facilities such as houses, the relief fund provided to community groups (POKMASs) up to now is still sourced from it, and this is the reason why the transition period from emergency response to rehabilitation and reconstruction (RR) phase is always extended [11]. This practice creates the risk of incompliance in using the on call budget. Housing reconstruction is more appropriately considered as part of the RR phase, hence the stimulating fund should come as a grant from either national or local annual budget.

Experience in major disaster situation such as the 2004 Aceh Earthquake, the 2006 Merapi volcanic eruption as well as 2006 Yogyakarta Earthquake and 2009 West Sumatra Earthquake shows that temporary or transition shelters are common practice and useful to provide the community decent living spaces instead of living in makeshift tents, which enable government to conduct a proper and well planned reconstruction process to provide safer housing to the community $[6,12,13,14]$. The initial government policy not to build transition shelters, and to complete reconstruction of houses within 6 months [14] has been putting pressure in the decision making on the strategic options to implement the reconstruction process, resulting in shorter term solutions which do not capitalize on the opportunity to build community awareness, knowledge and skill in building earthquake resistance house through incremental improvement of local, traditional house building technology.

\section{Conclusion}

Responding to major disasters like Lombok Earthquake is a complex process, which provide a good learning opportunity for both government, community, academic and private sectors.

An important lesson from the finding is that it is very important to define an appropriate strategy when housing reconstruction is to be commenced, considering multiple objectives that have to be achieved by reconstruction process, such as providing safer and more resilient housing while at the same time building more resilient communities which will be more responsible for their future safety against disaster. Sustainability issue is another important consideration for the reconstruction strategy. Full community participation is very important in the resilient building process. Provision of appropriate temporary or transition shelters is always recommended in such major disasters where proper reconstruction process which will always take time to complete can be implemented without to much pressure from humanitarian issues. To be able to initiate proper reconstruction process, setting up a well-structured and locally acceptable task force for managing and leading the process is a high priority, completed with a clear mechanism for fund disbursement, quality assurance, logistic supplies etc.

Last but not the least, to be able to handle properly such complex situation, government agencies responsible for post-disaster recovery and reconstruction, both at the national and local level should have been prepared long before any major disaster occurs, in particular in hazard prone regions. Mechanisms, guidelines, SOPs should be prepared, government officers as well as communities should be trained and exercised, models for post-disaster recovery and reconstruction task force organization should be prepared in advance. In short, preparedness should be built, not only for emergency response, but also for the recovery and reconstruction effort.

The authors wish to extend their gratitude and appreciation to the Institute of Research and Community Outreach of ITB who provided the grant for this research under the P3MI Program. A special appreciation is also extended to Mrs. Siti Nurul Hijjah, Chairperson of NTB Provincial Construction Service 
Development Board, for her invaluable support during the field work of this study.

\section{References}

1. Z. Sadiqi, B. Trigunarsyah, V. Coffey, Int. J. Project Manage. 35(5), 900-912 (2017)

2. M. Abe, C. Ochiai, K. Okazaki, Procedia Eng. 212, 411-418 (2018)

3. A. Bilau, E. Witt, I. Lill, Sustainability 10(11), 3929 (2018)

4. A. Bilau, E. Witt, I. Lill, Procedia Econ. Finance 21, 313-320 (2015)

5. M. Gjerde, S. de Sylva, Procedia Eng. 212, 527-534 (2018)

6. K. Suryanto Pribadi, D. Kusumastuti, S. Sagala, R. Wimbardana, Post-disaster housing reconstruction in Indonesia: Review and lessons from Aceh, Yogyakarta, West Java and West Sumatera earthquakes, in Disaster Recovery-Used or Misused Development Opportunity. Shaw R. (Ed.) (Springer, 2014)

7. K. Suryanto Pribadi, D. Rildova. Learning from recent Indonesian earthquakes: An overview to improve structural performance. in 14th World Conference on Earthquake Engineering, Beijing, China (2008)

8. K. Okazaki, et al, Reconstruction Practice in Aceh after 2004 Tsunami Disasters. in 14th World conference on earthquake engineering, Beijing (2008)

9. Instruksi Presiden Republik Indonesia No 35 (Tahun 2018)

10. Tim Pusat Studi Gempa Nasional, Kajian Rangkaian Gempa Lombok Provinsi Nusa Tenggara Barat 29 Juli 2018 (M6.4), 5 Agustus 2018 (M7.0), dan 19 Agustus 2018 (M6.9), 112 (Puslitbang Perumahan dan Pemukiman, Jakarta, 2019)

11. https://regional.kompas.com/read/2019/08/21/15183 251/ masa-transisi-darurat-pascagempa-lombokdiperpanjang-sampai-25-desember-2019?page $=$ all, (accessed 28 August 2019)

12. T. Trirahayu, Manajemen Bencana Erupsi Gunung Merapi oleh Badan Penanggulangan Bencana Daerah Kabupaten Sleman, (unpublished undergraduate Thesis, Faculty of Social Science, State University of Yogyakarta, 2015)

13. JRF- World Bank Indonesia, One Year after the Java Earthquake and Tsunami: Reconstruction Achievements and the Results of the Java Reconstruction Fund, (JRF Office Jakarta, 2007)

14. FCRC, Emergency Appeal Final Report - IndonesiaWest Sumatra Earthquake, Final report, Emergency appeal $n^{\circ}$ MDRID004 GLIDE $n^{\circ}$ TS-2009-000211IDN, (30 November 2011)

15. .https://www.tribunnews.com/nasional/2018/08/24/p emerintah-tak-bangun-hunian-sementara-bagikorban-gempa-di-lombok, (accessed 28 August 2019) 